\title{
Differentiation of Closely Related Oak-Associated Gram-Negative Bacteria by Label-Free Surface Enhanced Raman Spectroscopy (SERS)
}

\author{
Dorotèja Vaitiekūnaitè $^{1, *}$ and Valentinas Snitka ${ }^{2}$ \\ 1 Laboratory of Forest Plant Biotechnology, Institute of Forestry, Lithuanian Research Centre for Agriculture \\ and Forestry, Liepu Str. 1, Girionys, 53101 Kaunas, Lithuania \\ 2 Research Center for Microsystems and Nanotechnology, Kaunas University of Technology, \\ Studentu Str. 65, 51369 Kaunas, Lithuania; vsnitka@ktu.lt \\ * Correspondence: doroteja.vaitiekunaite@lammc.lt
}

Citation: Vaitiekūnaitè, D.; Snitka, V. Differentiation of Closely Related Oak-Associated Gram-Negative Bacteria by Label-Free Surface Enhanced Raman Spectroscopy (SERS). Microorganisms 2021, 9, 1969. https://doi.org/10.3390/

microorganisms 9091969

Academic Editor: Juan M. Gonzalez

Received: 9 August 2021

Accepted: 14 September 2021

Published: 16 September 2021

Publisher's Note: MDPI stays neutral with regard to jurisdictional claims in published maps and institutional affiliations.

Copyright: (C) 2021 by the authors Licensee MDPI, Basel, Switzerland. This article is an open access article distributed under the terms and conditions of the Creative Commons Attribution (CC BY) license (https:/ / creativecommons.org/licenses/by/ $4.0 /)$.

\begin{abstract}
Due to the harmful effects of chemical fertilizers and pesticides, the need for an eco-friendly solution to improve soil fertility has become a necessity, thus microbial biofertilizer research is on the rise. Plant endophytic bacteria inhabiting internal tissues represent a novel niche for research into new biofertilizer strains. However, the number of species and strains that need to be differentiated and identified to facilitate faster screening in future plant-bacteria interaction studies, is enormous. Surface enhanced Raman spectroscopy (SERS) may provide a platform for bacterial discrimination and identification, which, compared with the traditional methods, is relatively rapid, uncomplicated and ensures high specificity. In this study, we attempted to differentiate 18 bacterial isolates from two oaks via morphological, physiological, biochemical tests and SERS spectra analysis. Previous $16 S$ rRNA gene fragment sequencing showed that three isolates belong to Paenibacillus, 3-to Pantoea and 12-to Pseudomonas genera. Additional tests were not able to further sort these bacteria into strain-specific groups. However, the obtained label-free SERS bacterial spectra along with the highaccuracy principal component (PCA) and discriminant function analyses (DFA) demonstrated the possibility to differentiate these bacteria into variant strains. Furthermore, we collected information about the biochemical characteristics of selected isolates. The results of this study suggest a promising application of SERS in combination with PCA/DFA as a rapid, non-expensive and sensitive method for the detection and identification of plant-associated bacteria.
\end{abstract}

Keywords: plant-associated bacteria; surface enhanced Raman spectroscopy; SERS; label-free; Paenibacillus; Pseudomonas; Pantoea; principal component analysis; discriminant function analysis

\section{Introduction}

One of the limitations in microbiological research stems from the inability to easily differentiate bacterial samples at the species and/or strain level [1-5]. Over the years, many methods have been developed for microbial identification: morphological assessment, analytical profile index (API), immuno-assays (ex. ELISA), DNA sequencing, etc. The current "gold" standard, DNA sequencing, allows such discrimination based on the minute differences in bacterial genetic code, however, this method can be time consuming and economically inefficient, hence situationally ineffective [2,6-14].

Vibrational spectroscopy is a technique that has been used for the analysis of various chemicals, and in recent years has been successfully adapted for microbial research, showing great promise in becoming a novel diagnostic system in this field [4-6,8,9,15-18].

This technique stems from the fact that under excitation by light, analyte molecules will experience observable photon scattering. Raman scattering happens when the excitation energy is not the same as that of the scattered energy post interaction with the analyte molecule. Due to the low emission rate of scattered photons, an integration time of minutes 
is required to obtain useful spectra, however, ways to enhance this intrinsic aspect have been developed [18,19].

Raman spectroscopy, and its more sensitive variant (offering enhancements of up to $10^{15}$-fold $[8,16,20,21]$ )—surface enhanced Raman spectroscopy (SERS), are effective ways to discern bacterial samples up to strain level based on qualitative differences in cell chemistry $[6,8-10,15,16,22]$. This is sometimes referred to as vibrational "fingerprinting" or "barcoding", as each organism presents different and unique spectra $[4,23,24]$.

The sensitivity of the SERS technique is facilitated by substrate surface modifications. Analyte bioparticles are adsorbed on or placed in close proximity to a noble metal like silver (Ag) or gold (Au), nanoparticle (NP)-covered surfaces. In a sense this creates "hot spots", which focus and thus strengthen the signal that is emitted by the analyte molecules under excitation $[14,16,20,22,25]$. This allows for shorter integration times and increased sensitivity compared to standard Raman spectroscopy. SERS is advantageous due to its potential as a low cost, rapid, low volume, non-destructive, broad information content, high specificity and sensitivity diagnostic method $[1,9,10,18,20,22]$, also in part because analysis is easily performed in aqueous environments without interface [4,25]. In bacteriology, the efficacy of SERS was demonstrated with purified cultures, mixed and even single cell samples [6-9,13,15,20].

Spectra generated by SERS, provide the ability to carry out multivariate cluster analysis (ex. principal component analysis (PCA), discriminant function analysis (DFA), hierarchical cluster analysis (HCA), etc. or a combination thereof) that help the separation of different bacterial strains by determining both unique and common aspects of given spectra $[8,9,15,16,22]$. Moreover, these spectra help inform about the cell's molecular structure and composition, because spectral features correspond to functional groups $[6,7,20,22,26]$.

Despite the aforementioned advancements, the field is generally geared towards food and medical pathogen identification $[1,2,6-10,12,14,18,20,22,27,28]$. Furthermore, most experiments are conducted using well-studied species (ex. E. coli, Bacillus sp.). Wider use of this technique for bacteria sourced from environmental samples (ex. soil, plants) is, at the moment, rare [29].

In recent years, due to the limitations and negative effects of pesticides and chemical fertilizers, bacteria have been widely studied as potential biocontrol agents and biofertilizers [30]. This search for microbiological alternatives is expected to grow [31-33]. Future research in this field will rely heavily on the screening of new and/or yet thoroughly unstudied bacterial species [32-34]. Plant associated samples often contain substantial amounts of diverse bacterial species and potentially multiple, difficult to differentiate, strains within a single genus (ex. Pseudomonas spp.) [35-40]. In the field of plant-associated bacteriology, using SERS for the differentiation and identification of bacteria would likely prove to be highly beneficial and efficient $[16,22,29,30,41]$, as different species and even different strains of the same species may have vastly different effects on plant growth [42].

In this study we aimed to determine whether genetically highly homologous representative endophytic bacterial species from two oak trees from the same site could be effectively distinguished using SERS as an analytical tool in addition to other morphological, physiological and biochemical tests, to help in future biofertilizer research. Also, we aimed to produce specific SERS spectra for different oak-associated Pantoea, Pseudomonas and Paenibacillus isolates for public library building and future use.

With the help of PCA and DFA techniques, we were able to differentiate tested isolates up to strain level based on their SERS spectra. It is noteworthy, that the spectral characteristics of plant-associated bacteria homologous with Pseudomonas azotoformans and Paenibacillus tundrae species have not yet been described using the SERS method. This SERS-based protocol can be seen as an alternative, cost-effective and fast method for differentiating, identifying and characterizing different types of plant-associated bacteria and promote research in this and associated fields. 


\section{Materials and Methods}

Eighteen bacterial samples isolated from two English oaks (Quercus robur) were chosen for this study from our previously created library [35], 12 isolates from oak $\alpha$ and six from oak $\beta$. Both trees are from the same site, located in Lithuania (Table 1).

Table 1. Tree locations and their associated isolate identification numbers.

\begin{tabular}{ccc}
\hline Tree & Site (GPS Coordinates) & Isolate Identification No. \\
\hline Alfa $(\alpha)$ & $55.829832,26.217380$ & $21,27,30,32,33,33.1,34,36,40,46.1,46.2,49$ \\
\hline Bravo $(\beta)$ & $55.8301132,26.2168633$ & $24,29,35,37,47.1,47.2$ \\
\hline
\end{tabular}

\subsection{Morphological, Physiological and Biochemical Analysis}

Morphological, physiological and biochemistry tests were done in triplicates using fresh colonies, grown on low salt lysogeny broth (LB) agarized medium ( $\mathrm{pH}$ of 7.2 throughout the experiments) (Duchefa Biochemie, Haarlem, the Netherlands) each time. Bacteria were grown at $25^{\circ} \mathrm{C}$. All media were autoclaved prior to use at $121^{\circ} \mathrm{C}$ for $15 \mathrm{~min}$. Aseptic techniques were employed throughout the experiments.

\subsubsection{Colony Morphology}

Colony morphology was observed. Colony form, elevation, margin, color, opacity, smoothness, consistency and overall appearance on LB medium after 2 days of incubation were determined. Additionally, bacteria samples from overnight liquid LB cultures were visualized using $0.1 \%$ Gentian violet dye under $10,000 \times$ magnification. Bacteria shape, arrangement and size (average from three biological replicates and 10 technical replicates each) were observed.

\subsubsection{Biofilm Formation}

Bacterial ability to form biofilms was tested. A modified tissue culture plate method was used [43]. Bacteria were grown overnight in liquid LB. The next day $2 \mu \mathrm{L}$ of this suspension was pipetted into a sterile flat-bottomed 96-well polystyrene tissue culture plate, then each cell was filled with $198 \mu \mathrm{L}$ of LB medium supplemented with $1 \%$ glucose. $200 \mu \mathrm{L}$ of LB medium supplemented with $1 \%$ glucose was used as control. The plate was incubated overnight. After incubation, the plate was washed three times in a new container of sterile water each time. Then the plate was left to air dry. Subsequently, the biofilm layer was dyed using $0.1 \%$ Gentian violet solution for $15 \mathrm{~min}$. Afterward, the plate was washed and dried as previously described. After the fixation step, the biofilm layer was solubilized in ethanol (95\%) for $30 \mathrm{~min}$. Optical density (OD) was measured using Synergy HT MultiMode Microplate Reader (Biotek Instruments Inc., Bad Friedrichshall, Germany) at $630 \mathrm{~nm}$ ( $95 \%$ ethanol as control). Optical density cut-off (ODc) was calculated: ODc $=$ average OD of control +3 times the standard deviation of control. Biofilm formation capabilities were evaluated: weak biofilm $\sim$ ODc, moderate-2-4 ODc, strong biofilm—more than 4 ODc.

\subsubsection{Carbohydrate Use}

A modified phenol red test was used to determine how and which carbohydrates could these isolates use as a carbon source [44]. Lactose (L), fructose (F) (Merck, Darmstadt, Germany), maltose (M) (Avantor, Radnor, PA, USA), sucrose (Su) and glucose (G) (Duchefa Biochemie) were tested. LB liquid medium supplemented with $1 \%$ of one selected carbohydrate in each tube and $0.0018 \%$ of phenol red dye (Merck) was used. Carbohydrate solutions were filter sterilized and added to the medium after autoclaving. To check for gas production, an upside-down Durham tube was placed in each test tube. The tubes were then inoculated, gently mixed and incubated overnight in a stationary position. This allowed for the positive identification of isolates capable of anaerobically fermenting tested carbohydrates. To discern whether the bacteria were capable of aerobic use of carbohydrates, samples were also placed in a thermal shaker overnight. In both cases, color 
changes from red to yellow were observed. Bubbles in Durham tubes were indicative of gas production and color changes (from red to yellow) indicate a $\mathrm{pH}$ change due to acid production, hence the capacity for carbohydrate use.

\subsubsection{Antibiotic Susceptibility}

Bacterial susceptibility to various antibiotics was determined by using a modified Kirby-Bauer disk diffusion test [45]. Ampicillin (AM), cefotaxime (CTX), chloramphenicol (C), streptomycin (STP), ticarcillin (TIC) (Duchefa Biochemie) and kanamycin (K) (Panpharma, La Selle-en-Luitré, France) were used. Bacteria were grown overnight in liquid LB medium. The next day the bacterial suspension was adjusted to approximately $1.5 \times 10^{8} \mathrm{cfu} / \mathrm{mL}$. The suspension was cross-streaked on Mueller-Hinton agar (Condalab, Madrid, Spain) using sterile cotton swabs. Then sterile $0.5 \mathrm{~mm}$ paper disks were placed on top (6 disks per D8;9 cm plate, equally spaced). Filter sterilized antibiotic solutions were then pipetted onto the disks so that each disk contained a desired amount of antibiotics (10 $\mu \mathrm{g}$ of AM and STP, $30 \mu \mathrm{g}$ of CTX, C, K and $75 \mu \mathrm{g}$ of TIC per disk). The plates were incubated overnight in the dark. Inhibition zones were measured the next day and bacterial susceptibility was determined using antibiotic susceptibility charts [46-48].

\subsection{SERS Analysis}

We used SERS for bacterial vibrational fingerprinting. This method allowed us to sort bacterial isolates into groups using their vibrational patterns and to tentatively ascertain their molecular composition.

\subsubsection{Experimental Set Up for SERS Spectra Acquisition}

SERS spectra were recorded using Raman spectrometer (NTEGRA Spectra, NT-MDT Inc., Moscow, Russia) in an "upright" configuration with $532 \mathrm{~nm}$ laser as the excitation source. All spectra were calibrated to the first-order silicon longitudinal-optical (LO) phonon peak at $520 \mathrm{~cm}^{-1}$. The instrument is equipped with $2 \mathrm{~mW}$ power at the sample, a $100 \times$ objective (NA: 0.7$)$. A thermoelectrically cooled $\left(-60^{\circ} \mathrm{C}\right)$ charge-coupled device (CCD) was used as a detector. The spectral resolution was $1.1 \mathrm{~cm}^{-1}$.

\subsubsection{SERS Substrate Preparation}

The preparation of SERS substrates was based on direct silver ions reduction by elemental silicon [49]. Silicon slides were cut into small pieces $(1.5 \times 1.5 \mathrm{~cm})$. Then they were polished $(2 \mathrm{~min}$ ) with glass paper to rough up the silicon surface. Such prepared slides with etched $100 \mathrm{~mm}$ deep wells were washed with pure ethanol, then dried under nitrogen flow and kept in closed Petri dishes until use.

Preprepared $\mathrm{HF}(24 \%)$ and $\mathrm{AgNO}_{3}(20 \mathrm{mM})$ solutions were mixed in a ratio of 1:1 v/v. Polished silicon slides were immersed in the reaction mixture for $2 \mathrm{~s}$, then immediately transferred to a container with distilled water $\left(\mathrm{dH}_{2} \mathrm{O}\right)$ and finally dried under nitrogen flow. The dried substrate slides were immediately used for SERS spectra measurements.

\subsubsection{Bacteria Sample Preparation for SERS}

Bacteria from our library were transferred using a plastic loop into liquid LB. Overnight cultures $\left(\sim 10^{6} \mathrm{cfu} / \mathrm{mL}\right)$ were centrifuged at $3500 \times g$ and washed 3 times with $0.9 \% \mathrm{NaCl}$ solution. After the last wash bacteria were placed in $200 \mu \mathrm{L}$ of $0.9 \% \mathrm{NaCl}[12,24]$. Using a sterile pipette, $20 \mu \mathrm{L}$ of the suspension was then placed on the substrate silicon slide and immediately transferred to the Raman microscope for data acquisition. It should be noted that the SERS spectra measurements were performed in the presence of bacteria in liquid suspension and by scanning the sample, thus reducing the thermal effect of the laser on the bacteria, i.e., scanning live samples [50]. 


\subsubsection{SERS Spectra Acquisition}

To ensure the reproducibility of the SERS spectra, 50 spectra from each bacterium were obtained from the suspension drop on the SERS substrate. The single spectrum was acquired as a summary spectrum by scanning $100 \times 100$ micron area during the SERS spectra acquisition to optimize the Raman signal strength. The bacterial spectra dataset was collected from the 50 randomly selected spots in the sample. The acquisition time of Raman scattering signal was $20 \mathrm{~s}$. From the 50 acquired spectra, 16 spectra, based on their signal-to-noise ratio, were selected for processing. The resulting SERS spectra were analyzed and edited using Nova 1.1.0.1840 (NT-MDT Inc., Moscow, Russia) and SpectraGryph 1.2.14 software (Dr. Friedrich Menges, Obersdorf, Germany) with cropping to $600-1800 \mathrm{~cm}^{-1}$, removal of background fluorescence, normalization to the intensity of maximum amplitude, baseline correction - 5\% coarseness [51].

Vibrational bands were noted (peak finding threshold $-0.5 \%$, position tolerance $-0.4 \%$ ) and tentative band assignments were determined based on literature sources.

\subsubsection{Multivariate Cluster Analyses}

Bacterial differentiation was done based on cluster map methodology using PCA and DFA with Raman processing software [52] in the MATLAB (2012) environment (MathWorks, Inc., Natick, MA, USA). PCA was employed for this study to highlight the variability existing in the spectral data set. The reference spectrum for a single isolate used for DFA was produced as an average spectrum of the 16 experimentally acquired spectra. In DFA a leave-one-out cross-validation method was used.

\section{Results}

\subsection{Morphological, Physiological and Biochemical Analysis}

Eighteen bacterial isolates were studied. Twelve from oak $\alpha$ and six from oak $\beta$. Previously $16 S r R N A$ gene fragments were successfully sequenced for all the isolates [35]. All of them were identified to genus level (Table 2). Colony morphology and DNA sequencing results allowed to presumptively divide 18 isolates into four morphotypes, identified as A-D (Table 2, Figure 1). Morphotypes A and D were isolated from both trees, while morphotypes $B$ and $C$ were only isolated from different trees each. NCBI Blast results showed that morphotype A was from the Paenibacillus genus and was closely related to Paenibacillus tundrae, morphotype B was closely related to Pantoea agglomerans, morphotype C-to Pseudomonas brenneri/proteolytica and morphotype D-to Pseudomonas azotoformans.

Table 2. Colony morphology and $16 S$ rRNA sequencing results of 18 bacterial isolates and their corresponding morphotypes (in part based on [35]).

\begin{tabular}{|c|c|c|c|}
\hline $\begin{array}{c}\text { Isolate } \\
\text { Identification Code }\end{array}$ & Colony Morphology & Morphotype & $\begin{array}{c}\text { Closest NCBI Match, } \\
\text { Accession No., \% Identity }\end{array}$ \\
\hline $21,33.1,35$ & $\begin{array}{l}\text { Colonies are circular, flat with a slightly undulate } \\
\text { margin, smooth and glistening, off-white with a grey } \\
\text { bull's eye in the center, translucent and mucoid. }\end{array}$ & A & $\begin{array}{l}\text { Paenibacillus tundrae A10b, } \\
\text { NR_044525.1, 99.32-99.46\% }\end{array}$ \\
\hline $27,30,34$ & $\begin{array}{l}\text { Colonies are circular, flat, cream colored, translucent, } \\
\text { smooth and glistening, butyrous, the margin is entire. } \\
\text { Changes LB agar medium color to bright yellow. A } \\
\text { small spindle formation can be observed at the center } \\
\text { of the colony with } 40 \times \text { magnification. }\end{array}$ & B & $\begin{array}{c}\text { Pantoea agglomerans DSM 3493, } \\
\text { NR_041978.1,99.64-99.97\% }\end{array}$ \\
\hline 24,29 & $\begin{array}{l}\text { Colonies are circular, raised, buff color, glistening and } \\
\text { butyrous, the center of the colony is rough, and the } \\
\text { edges are smooth, the margin is entire. The colonies } \\
\text { change color of LB agar medium to bright yellow. }\end{array}$ & $\mathrm{C}$ & $\begin{array}{l}\text { Pseudomonas brenneri CFML } \\
\text { 97-391, NR_025103.1,99.86\%; } \\
\text { Pseudomonas proteolytica CMS } \\
\text { 64, NR_025588.1,99.59\% }\end{array}$ \\
\hline $\begin{array}{l}32,33,36,37,40,46.1 \\
\quad 46.2,47.1,47.2,49\end{array}$ & $\begin{array}{l}\text { Colonies are circular, flat, cream colored, translucent, } \\
\text { smooth and glistening, butyrous, the margin is entire. } \\
\text { Changes LB agar medium color to bright yellow. }\end{array}$ & $\mathrm{D}$ & $\begin{array}{l}\text { Pseudomonas azotoformans } \\
\text { NBRC 12693, NR_113600.1, } \\
\text { 99.66-99.79\% }\end{array}$ \\
\hline
\end{tabular}




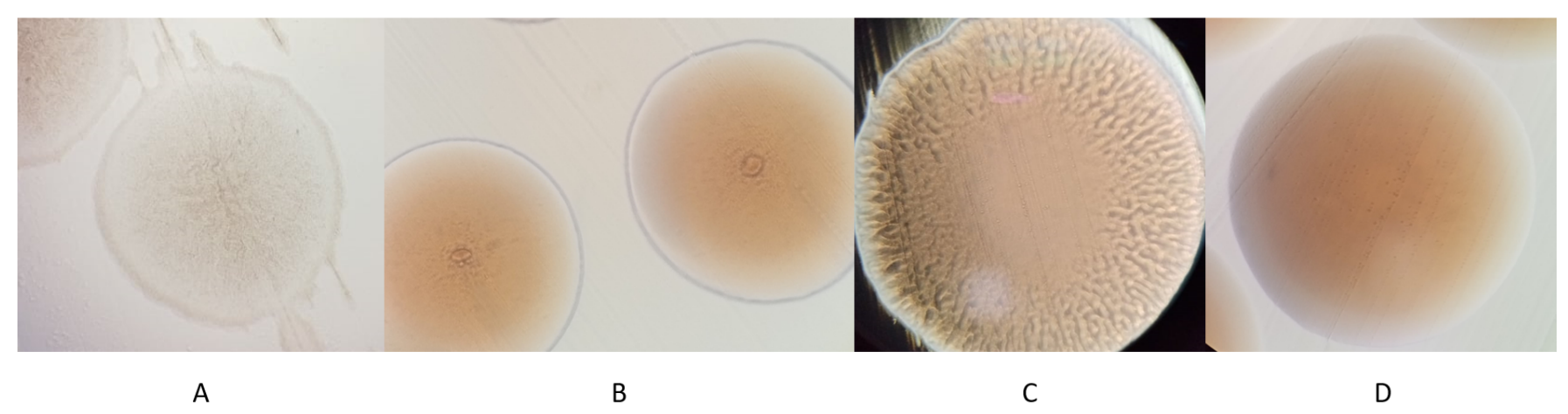

Figure 1. Colony morphology of 4 morphotypes (A-D) under $40 \times$ magnification on LB agar medium after 2 days incubation.

Bacteria were all similar in diameter-0.28-0.45 $\mu \mathrm{m}$. Results from morphological, physiological and biochemistry tests also divided the isolates into four distinct groups that coincided with previously described morphotypes (Table 3).

Table 3. Analyzed properties (size, biofilm formation, carbohydrate use, antibiotic susceptibility) of 18 bacterial isolates used in this study (in bold-isolates selected for further SERS analysis) *.

\begin{tabular}{|c|c|c|c|c|c|c|c|c|c|c|c|c|c|c|}
\hline \multirow{2}{*}{$\frac{0}{2}$} & \multirow{2}{*}{ ن } & \multirow{2}{*}{ 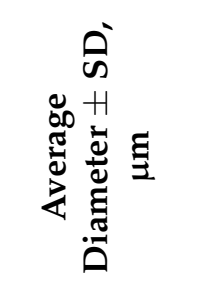 } & \multirow{2}{*}{ 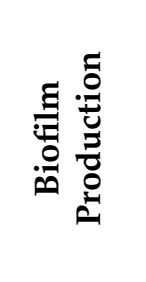 } & \multicolumn{6}{|c|}{ Antibiotic Disk Diffusion Test } & \multicolumn{5}{|c|}{ Carbohydrate Use } \\
\hline & & & & $\frac{0}{\sum_{4}}$ & $\begin{array}{r}\stackrel{P}{0} \\
\dot{1} \\
\ddot{U}\end{array}$ & $\begin{array}{l}\stackrel{P}{~} \\
\text { ú }\end{array}$ & $\begin{array}{l}\text { Pे } \\
\text { ¿ }\end{array}$ & 号 & $\stackrel{n}{\mathscr{U}}$ & L & $\mathbf{M}$ & $\mathrm{Su}$ & G & $\mathbf{F}$ \\
\hline \multirow{3}{*}{ A } & 21 & $0.444 \pm 0.03$ & - & $S$ & $\mathrm{R}$ & $\mathrm{S}$ & $\mathrm{S}$ & $\mathrm{R}$ & $\mathrm{R}$ & Ac & Ac & Ac & Ac & Ac \\
\hline & 33.1 & $0.361 \pm 0.039$ & - & $S$ & $\mathrm{R}$ & $S$ & $\mathrm{~S}$ & $\mathrm{R}$ & $\mathrm{R}$ & Ac & Ac & Ac & Ac & Ac \\
\hline & 35 & $0.43 \pm 0.042$ & - & $S$ & $\mathrm{R}$ & $S$ & $\mathrm{~S}$ & $\mathrm{R}$ & $\mathrm{R}$ & Ac & Ac & Ac & Ac & Ac \\
\hline \multirow{3}{*}{ B } & 27 & $0.324 \pm 0.041$ & - & $\mathrm{S}$ & $\mathrm{S}$ & $\mathrm{S}$ & $\mathrm{S}$ & $\mathrm{S}$ & $\mathrm{R}$ & Ac & Ac & Ac & Ac & Ac \\
\hline & 30 & $0.352 \pm 0.04$ & - & $S$ & $S$ & $S$ & $\mathrm{~S}$ & $\mathrm{~S}$ & $\mathrm{R}$ & Ac & Ac & Ac & Ac & Ac \\
\hline & 34 & $0.438 \pm 0.028$ & - & $S$ & $S$ & $S$ & $\mathrm{~S}$ & $\mathrm{~S}$ & $\mathrm{R}$ & Ac & Ac & Ac & Ac & Ac \\
\hline \multirow{2}{*}{$\mathrm{C}$} & 24 & $0.326 \pm 0.033$ & moderate & $\mathrm{R}$ & $\mathrm{R}$ & $\mathrm{R}$ & $\mathrm{S}$ & $\mathrm{R}$ & $\mathrm{R}$ & - & - & - & Ac & - \\
\hline & 29 & $0.284 \pm 0.014$ & moderate & $\mathrm{R}$ & $\mathrm{R}$ & $\mathrm{R}$ & $S$ & $\mathrm{R}$ & $\mathrm{R}$ & - & - & - & Ac & - \\
\hline \multirow{10}{*}{$\mathrm{D}$} & 32 & $0.366 \pm 0.021$ & - & $\mathrm{R}$ & $\mathrm{R}$ & $\mathrm{R}$ & $S$ & $\mathrm{R}$ & $\mathrm{R}$ & - & - & - & Ac & - \\
\hline & 33 & $0.338 \pm 0.03$ & - & $\mathrm{R}$ & $\mathrm{R}$ & $\mathrm{R}$ & $\mathrm{S}$ & $\mathrm{R}$ & $\mathrm{R}$ & - & - & - & Ac & - \\
\hline & 36 & $0.447 \pm 0.047$ & - & $\mathrm{R}$ & $\mathrm{R}$ & $\mathrm{R}$ & $S$ & $\mathrm{R}$ & $\mathrm{R}$ & - & - & - & Ac & - \\
\hline & 37 & $0.34 \pm 0.023$ & - & $\mathrm{R}$ & $\mathrm{R}$ & $\mathrm{R}$ & $S$ & $\mathrm{R}$ & $\mathrm{R}$ & - & - & - & Ac & - \\
\hline & 40 & $0.427 \pm 0.037$ & - & $\mathrm{R}$ & $\mathrm{R}$ & $\mathrm{R}$ & $S$ & $\mathrm{R}$ & $\mathrm{R}$ & - & - & - & Ac & - \\
\hline & 46.1 & $0.426 \pm 0.036$ & - & $\mathrm{R}$ & $\mathrm{R}$ & $\mathrm{R}$ & $S$ & $\mathrm{R}$ & $\mathrm{R}$ & - & - & - & Ac & - \\
\hline & 46.2 & $0.338 \pm 0.028$ & - & $\mathrm{R}$ & $\mathrm{R}$ & $\mathrm{R}$ & $S$ & $\mathrm{R}$ & $\mathrm{R}$ & - & - & - & Ac & - \\
\hline & 47.1 & $0.43 \pm 0.073$ & - & $\mathrm{R}$ & $\mathrm{R}$ & $\mathrm{R}$ & $S$ & $\mathrm{R}$ & $\mathrm{R}$ & - & - & - & Ac & - \\
\hline & 47.2 & $0.45 \pm 0.042$ & - & $\mathrm{R}$ & $\mathrm{R}$ & $\mathrm{R}$ & $\mathrm{S}$ & $\mathrm{R}$ & $\mathrm{R}$ & - & - & - & Ac & - \\
\hline & 49 & $0.405 \pm 0.042$ & - & $\mathrm{R}$ & $\mathrm{R}$ & $\mathrm{R}$ & $S$ & $\mathrm{R}$ & $\mathrm{R}$ & - & - & - & Ac & - \\
\hline
\end{tabular}


Morphotype A was sensitive to AM, C and K, and capable of fermenting all the carbohydrates tested. Morphotype B was resistant to TIC and capable of fermenting all the carbohydrates tested. Morphotype $\mathrm{C}$ formed biofilms, was sensitive to $\mathrm{K}$ and capable of using $\mathrm{G}$ as a nutrient. Morphotype $\mathrm{D}$ was sensitive to $\mathrm{K}$ and capable of using $\mathrm{G}$ as a nutrient.

\subsection{SERS Analysis}

\subsubsection{Structural Analysis Based on SERS Spectra}

Eight isolates were selected for SERS analysis. As Pseudomonas sp. are difficult to differentiate to species level via $16 S$ rRNA gene sequencing and since isolates 24 and 29 are of the same origin, we treated them as equal. Thus, for further analysis, isolate 24 and isolates 37 and 49 from the pseudomonad group were chosen. Isolates 37 and 49 were highly homologous and from different sources. Isolates 33.1 and 35 were selected from the Paenibacillus sp. group, because based on genetic tests and additional experiments, they were identical, but of different origins. Moreover, isolates 27, 30 and 34, representing Pantoea agglomerans, were selected for vibrational analysis. They were all sourced from the same tree, however, they exhibited differences in plant hormone, indole-3-acetic acid (IAA), production in previous studies [35]. To determine the efficacy of the proposed bacterial differentiation methodology, the focus was put on within-group differences of isolates $33.1 / 35,27 / 30 / 34$ and $37 / 49$.

Band peaks and their respective intensities are used to sort bacteria in relation to one another [7,29,50]. Representative spectra acquired during this study are shown in Figure 2. The stacked mean spectra of all 8 isolates are shown in Figure 3.

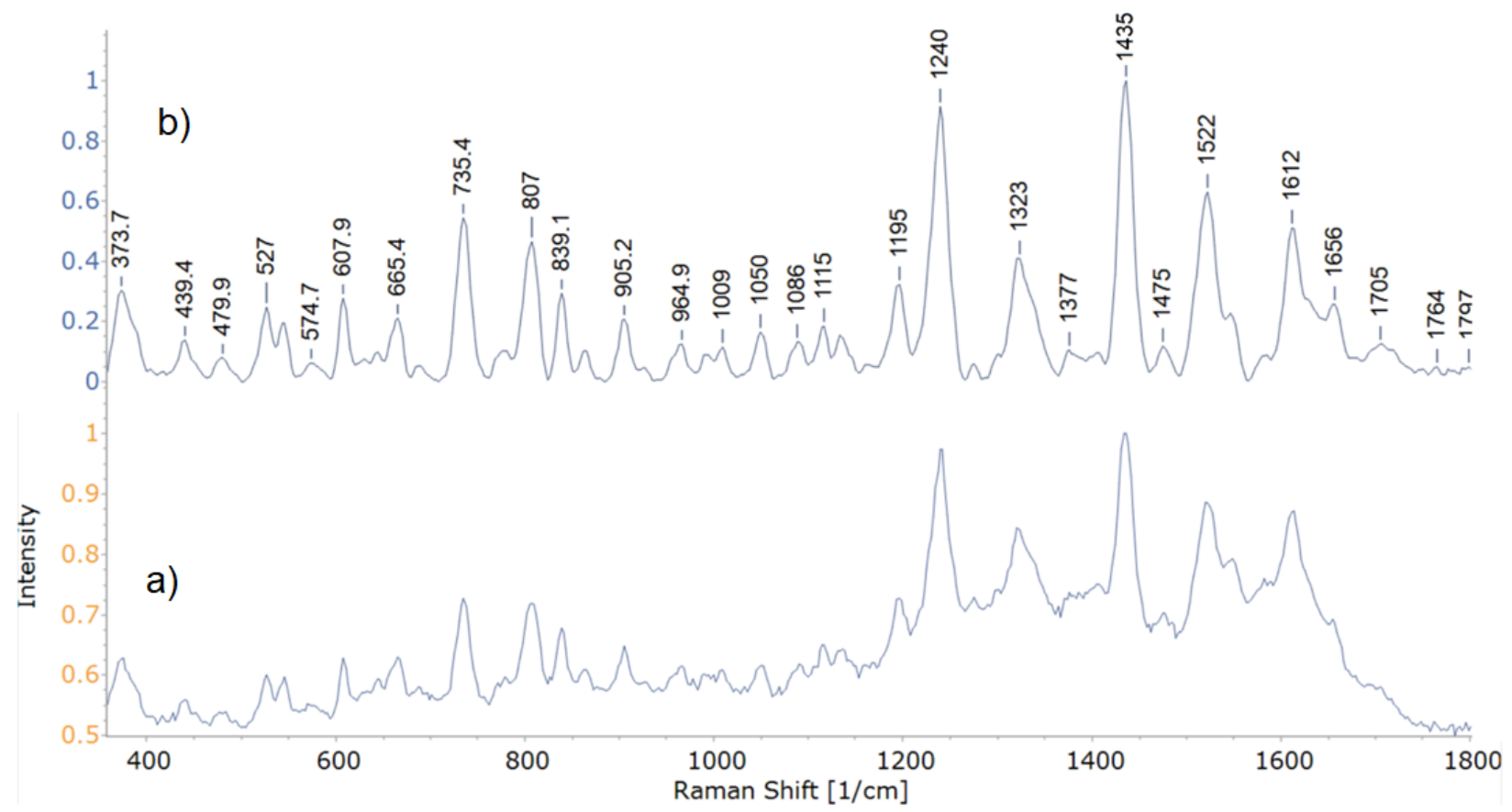

Figure 2. Representative experimental (a) and preprocessed (b) spectra of isolate 27. 


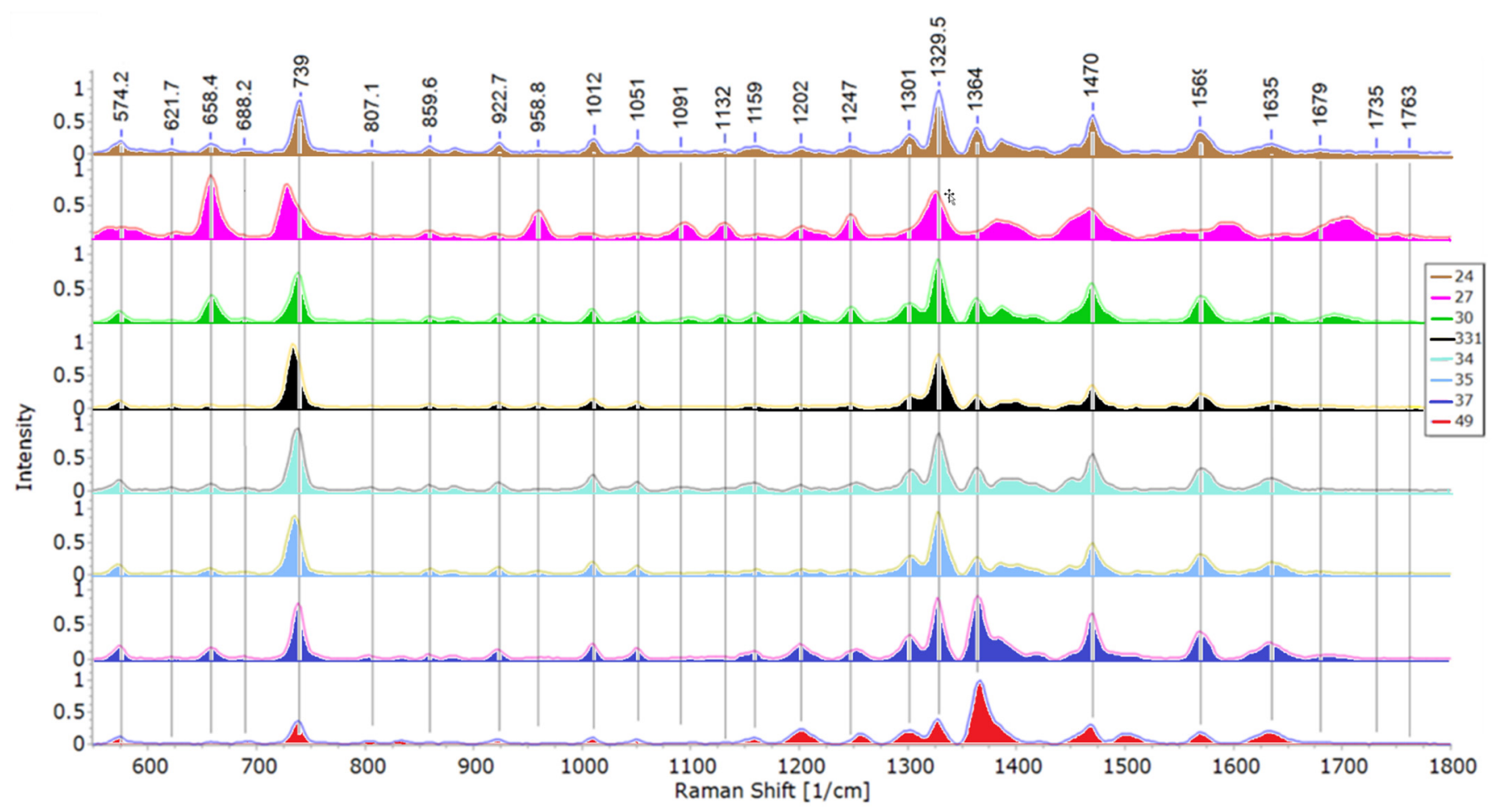

Figure 3. Stacked mean spectra of 8 bacterial isolates with peak values for the most notable bands.

As mentioned previously, peaks in the SERS spectra are linked with functional groups $[6,7,20,22,26]$. These groups represent components of bacterial cells $[8,17]$, most often either extracellular polymers [17] or more likely degradation metabolites $[50,53]$ or parts of the outer membrane in Gram negative bacteria [13]. We present tentative SERS spectra band assignments in Table 4.

Table 4. Tentative assignments of the most notable surface enhanced Raman spectral bands of mean spectra from 8 tested isolates.

\begin{tabular}{|c|c|c|c|c|c|c|c|c|}
\hline \multicolumn{8}{|c|}{ Peak Wavenumber, $\mathrm{cm}^{-1}$} & \multirow{2}{*}{ Tentative Band Assignments * } \\
\hline 24 & 27 & 30 & 33.1 & 34 & 35 & 37 & 49 & \\
\hline & 563.38 & & & & & & & $\mathrm{~T}, \mathrm{G}[10,54]$ \\
\hline 574.21 & & 573.52 & 573.01 & 573.47 & 572.08 & 573.63 & 573.57 & $\begin{array}{l}\text { Deformation of } \mathrm{C}=\mathrm{O}-\mathrm{C} \text { in lipids [55] or } \\
\operatorname{Trp}[54,56,57] \text { or carbohydrates }[58]\end{array}$ \\
\hline 621.65 & 625.66 & 622.17 & 623.31 & 620.93 & 622.5 & 622.03 & & $\begin{array}{l}\text { C-C twisting mode of Phe ring } \\
{[7,10,29,54,56]}\end{array}$ \\
\hline 658.43 & 657.8 & 658.53 & 657.42 & 657.71 & 657.09 & 657.93 & 658.28 & $\begin{array}{l}\text { G, ring breathing mode }[9,59-61] \text { or } \\
\text { amino acids COO-[62] }\end{array}$ \\
\hline 688.19 & & & & 689.83 & 689.18 & 689.93 & 692.23 & C-S stretch $[26,57]$ or Gly [54] \\
\hline 739.19 & 727.8 & 737.96 & 733.83 & 737.14 & 734.21 & 738.08 & 737.93 & $\begin{array}{c}\text { A, glycosidic ring breathing } \\
{[9,10,15,26,63,64]}\end{array}$ \\
\hline 807.14 & 804.25 & 804.8 & & 805.45 & 807.23 & 801.95 & 804.72 & $\mathrm{O}-\mathrm{P}-\mathrm{O}[1,26]$ or C-N stretch [20] \\
\hline 836.42 & & 832.58 & & 831.81 & & 830.52 & 832.87 & $\begin{array}{c}\text { O-P-O stretching in T }[10,59] \text { or Tyr } \\
{[29,59]}\end{array}$ \\
\hline 859.65 & 858 & & 858 & 859.14 & 859.65 & 858.69 & & $\begin{array}{c}\text { Phosphodiester, deoxyribose related to T } \\
{[4,10] \text { or Tyr }[29]}\end{array}$ \\
\hline 882.32 & & 879.93 & & 882.2 & & 880.81 & & $\begin{array}{l}\text { T, ring bending [10], stretching of } \mathrm{C}-\mathrm{N} \text { or } \\
\mathrm{C}-\mathrm{O}-\mathrm{N} \text { or deformation of } \mathrm{C}-\mathrm{C}-\mathrm{H}[65]\end{array}$ \\
\hline 922.65 & 919.72 & 922.49 & 920.2 & 922.4 & 922.32 & 922.51 & 922.53 & C-COO- stretch in carbohydrates $[26,66]$ \\
\hline
\end{tabular}


Table 4. Cont.

\begin{tabular}{|c|c|c|c|c|c|c|c|c|}
\hline \multicolumn{8}{|c|}{ Peak Wavenumber, $\mathrm{cm}^{-1}$} & \multirow{2}{*}{ Tentative Band Assignments * } \\
\hline 24 & 27 & 30 & 33.1 & 34 & 35 & 37 & 49 & \\
\hline \multirow[t]{3}{*}{958.79} & 959.67 & 957.92 & 958.24 & & 958.22 & & & $\begin{array}{l}\mathrm{C}-\mathrm{N} \text { stretching }[7,10,29,67] \text { or } \mathrm{C}-\mathrm{C} / \mathrm{C}-\mathrm{O} \\
\text { stretching in membrane proteins }[10]\end{array}$ \\
\hline & & & & & & 966.22 & & $\begin{array}{c}\mathrm{C}-\mathrm{N} \text { stretch }[26] \text { or } \mathrm{C}=\mathrm{C} \text { deformation } \\
\text { in } \mathrm{G}[61]\end{array}$ \\
\hline & 1005.6 & & & & & & & Phe $[7,10,29]$ \\
\hline 1011.9 & & 1009.1 & 1009.5 & 1010 & 1009.6 & 1009.5 & 1009.4 & Phe $[68,69]$ or $\operatorname{Trp}[54,57]$ \\
\hline 1051 & 1050.3 & 1050.6 & 1050.9 & 1050.8 & 1051.1 & 1050.4 & 1050 & $\begin{array}{l}\text { Phenylalanine (the in-plane } \mathrm{C}-\mathrm{H} \\
\text { bending mode) [69] or stretching of } \\
\mathrm{C}-\mathrm{O} / \mathrm{CH}_{2}-\mathrm{OH} \text { in lipids [70] }\end{array}$ \\
\hline \multirow[t]{3}{*}{1091.2} & 1094.7 & 1099.2 & & 1089.9 & & & & $\begin{array}{c}\mathrm{PO}_{2}^{-} \text {of nucleic acid stretching }[10,20,29] \\
\text { or deformation in carbohydrates }(\mathrm{C}-\mathrm{C} \text {, } \\
\mathrm{C}-\mathrm{O},-\mathrm{COH})[7,65,67]\end{array}$ \\
\hline & & & & & 1116.4 & 1119.2 & & $\operatorname{Trp}[65]$ \\
\hline & 1131.1 & 1129.6 & & & & & & $\begin{array}{l}\mathrm{C}-\mathrm{N} \text { and } \mathrm{C}-\mathrm{C} \text { stretching in } \\
\text { carbohydrates }[61,69] \text { or }=\mathrm{C}-\mathrm{C}=\text { in } \\
\text { unsaturated fatty acids in lipids }[16,29]\end{array}$ \\
\hline 1159.3 & 1161.7 & 1159.8 & 1158.5 & 1158.5 & 1159.6 & 1158.3 & 1158.7 & $\begin{array}{c}\mathrm{C}-\mathrm{C} / \mathrm{C}-\mathrm{N} \text { stretching in proteins }[10] \text { or } \\
\text { carotenoids }[15,29]\end{array}$ \\
\hline 1202 & 1201.9 & 1203 & 1200.8 & 1201.5 & 1201.6 & 1201.1 & 1201.7 & $\begin{array}{c}=\mathrm{C}-\mathrm{C}=\text { in lipids [69] or aromatic amino } \\
\text { acids in proteins [71] }\end{array}$ \\
\hline 1247.2 & 1247.4 & 1247.6 & 1246.4 & 1254.8 & 1250.9 & 1252.5 & 1256.9 & Amide III $[10,26,29,62,65]$ \\
\hline 1301.4 & & 1301.7 & & 1303.1 & & 1301.6 & 1300.4 & $\mathrm{CH}_{2}$ twist in lipids $[10,55]$ \\
\hline 1328.4 & 1325.2 & 1327.7 & 1328.2 & 1328.5 & 1328 & 1327.4 & 1327.3 & A $[9,62,63,70,72]$ \\
\hline \multirow[t]{3}{*}{1363.7} & & 1363.3 & 1363.5 & 1363.8 & 1363.8 & 1364.7 & 1366.4 & $\begin{array}{l}\text { Trp [10] or C-H deformation in } \\
\text { proteins / COO- deformation }[5,73]\end{array}$ \\
\hline & 1383 & 1387.1 & & 1388.8 & 1386.3 & & & $\begin{array}{l}\text { COO- stretching in proteins }[66,74] \text { or } \\
\qquad \mathrm{CH}_{3} \text { bending [29] }\end{array}$ \\
\hline & & & 1398.8 & & & & & $\begin{array}{l}\text { COO- symmetric stretching }[1,75] \text { or } \\
\text { deformation of } \mathrm{CH}_{3}[76]\end{array}$ \\
\hline 1421.2 & & & & & & & & $\begin{array}{l}\mathrm{CH}_{2} \text { deformation in lipids }[50,66,68] \text { or } \\
\text { A, G }[66,71]\end{array}$ \\
\hline \multirow[t]{3}{*}{1470.4} & 1467.8 & 1469.6 & 1470 & 1470 & 1470.2 & 1469.6 & 1468.8 & $\begin{array}{l}\text { Lipids }[9,10] \text { or deformation of } \mathrm{C}-\mathrm{H} \text { in } \\
\text { proteins }[65,69]\end{array}$ \\
\hline & & & & & & & 1501.2 & $\begin{array}{l}\text { Fatty acids in lipids [5,73] or carotenoids } \\
\text { [29] or amino acids [74] }\end{array}$ \\
\hline & & & 1511.1 & & 1511.5 & & & Carotenoids $[29,77]$ or Phe $[70]$ \\
\hline \multirow[t]{2}{*}{1569.4} & & 1570.5 & 1570.1 & 1570.9 & 1569.9 & 1569.5 & 1569.3 & Tyr/proteins $[69,70]$ or A/G [78] \\
\hline & 1592.4 & & & & & & & Proteins $[10]$ or A/G $[1,7]$ or Tyr $[72,79]$ \\
\hline \multirow[t]{2}{*}{1634.5} & & 1634.7 & 1636.8 & 1634.5 & 1635.5 & 1633.1 & 1633 & Amide I in lipids $[10,26,72]$ \\
\hline & 1647.9 & & & & & & & Amide I [69] or T $[29,68]$ \\
\hline \multirow[t]{3}{*}{1679.2} & & 1694 & 1681.1 & 1684.3 & 1676.6 & & 1682.8 & Amide I [10,62,71,75] \\
\hline & 1703.4 & & & & & & & $\mathrm{C}=\mathrm{O}[5,71]$ \\
\hline & 1750.2 & & & & & & & $\mathrm{C}=\mathrm{O}$ stretching $[5,21]$ \\
\hline
\end{tabular}

* T: thymine, G: guanine, Trp: tryptophan, Phe: phenylalanine, Gly: glycine, A: adenine, Tyr: tyrosine.

Minor Raman shifts in various references seen in Table 4 are due to methodological variations $[7,15,17]$ as well as indicative of molecular differences [50], facilitating successful differentiation.

As can be seen from Figure $4 a, b$, isolate 27 diverged greatly from other tested isolates. It exhibits several peaks, that weren't observed in other test subjects (peaks at 563, 1005, $1592,1647,1703$ and $1750 \mathrm{~cm}^{-1}$ ). While peaks at 563, 1005, 1592 and $1647 \mathrm{~cm}^{-1}$, are likely 
indicative of a shift, bands in the $1700 \mathrm{~cm}^{-1}$ range, linked with $\mathrm{C}=\mathrm{O}$ deformation, are wholly unique to this isolate. Isolates 30 and 34 from Pantoea agglomerans group didn't show such differences, however, they diverged by the absence of peaks at 688,858 and $958 \mathrm{~cm}^{-1}$. Additionally, isolate 30 exhibited a peak at $1131 \mathrm{~cm}^{-1}$, related to deformations of $\mathrm{C}-\mathrm{C}, \mathrm{C}-\mathrm{N}$ in carbohydrates or $=\mathrm{C}-\mathrm{C}=$ in lipids, alongside isolate 27 , while this peak was absent from the spectra of isolate 34 .

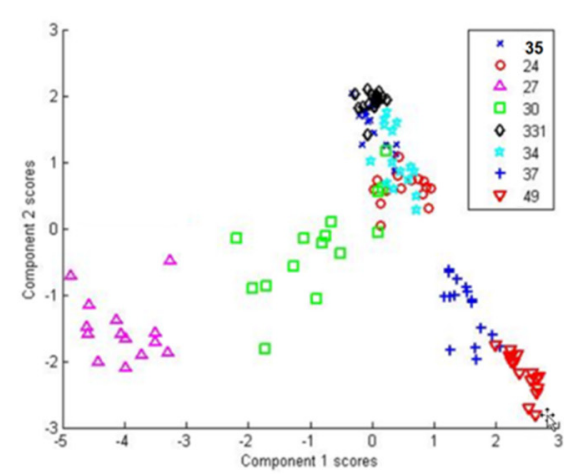

a

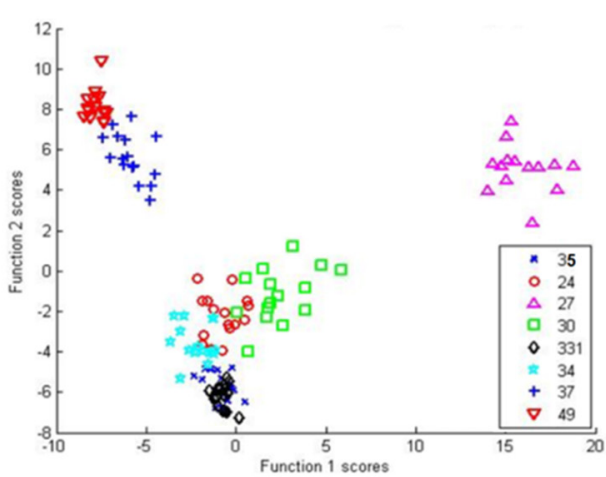

b

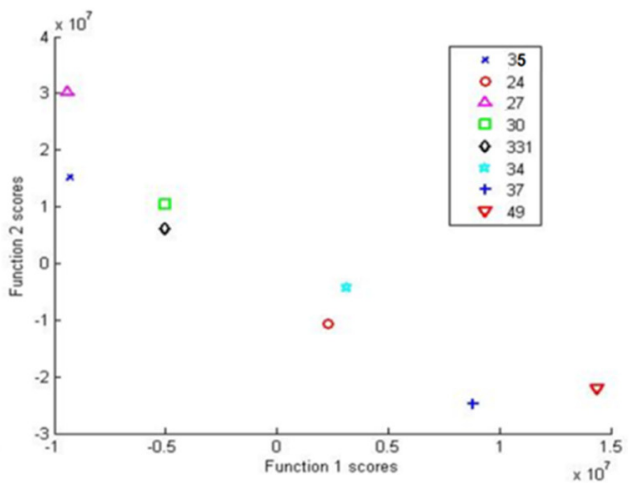

C

Figure 4. Principal component analysis (PCA) score plot for all 8 isolates (a), discriminant function analysis (DFA) for all eight isolates based on PCA scores (b) and DFA of all eight isolates using raw spectral data (c).

Isolates 33.1 and 35 from Paenibacillus sp. group exhibited similarities in their spectra and were grouped close in PCA and DFA score maps (Figures 4a and 6a). However, as can be seen by their raw data DFA (Figure 6b), there were differences. Isolate 33.1 has a notable peak at $1398 \mathrm{~cm}^{-1}$, linked with $\mathrm{COO}-$ or $\mathrm{CH}_{3}$ deformations, and lacks notable peaks at 688 , 804 and $1383 \mathrm{~cm}^{-1}$, while isolate 35 has a notable band at $1116 \mathrm{~cm}^{-1}$, potentially related to Trp. The peak at $1398 \mathrm{~cm}^{-1}$ is likely related to peaks at $\sim 1388 \mathrm{~cm}^{-1}$, indicating a shift, rather than an absence. Moreover, the peak at $1116 \mathrm{~cm}^{-1}$ is unique for isolate 35 , since isolate 33.1 doesn't exhibit a peak related to that area.

Isolate 24 exhibits a peak at $1421 \mathrm{~cm}^{-1}$, linked with lipids or carbohydrates, that the other two isolates, 37 and 49, from the pseudomonads group lack, while missing a peak at $1383 \mathrm{~cm}^{-1}$. Isolate 37 has peaks at $966 \mathrm{~cm}^{-1}$ and $1119 \mathrm{~cm}^{-1}$ and lacks a peak at $1679 \mathrm{~cm}^{-1}$ (all linked with proteins), that isolate 49 exhibits. The peak at $966 \mathrm{~cm}^{-1} \mathrm{can}$ potentially be related to the peak at $\sim 958 \mathrm{~cm}^{-1}$, both, based on past studies, linked with C-N deformations. Furthermore, isolate 49 doesn't show notable peaks at 622,858 or $882 \mathrm{~cm}^{-1}$, while exhibiting a peak at $1501 \mathrm{~cm}^{-1}$, which according to our findings, is linked with various organic compounds, carotenoids among them. Most of these peaks are unique to isolate 49 , except for the peak near $1500 \mathrm{~cm}^{-1}$, which may be a shift from the carotenoid band at $\sim 1510 \mathrm{~cm}^{-1}$.

\subsubsection{Differentiation via Multivariate Cluster Analyses}

Cluster analysis methods were used for bacterial differentiation. Figure $4 \mathrm{a}$ shows the PCA scatter plot of the eight bacterial isolates based on 14 principal components (PCs) accounting for $95.1 \%$ of the variance. Here, the scatter plot presents the ability of the SERS spectral analysis to differentiate among the different types of bacteria.

SERS data of the tested isolates were also classified using DFA. Eleven PC results were used as independent input variables in DFA (Figure 4b), which further reduced the spectral dimension, however, the groupings remained similar to those of the PCA. Furthermore, DFA from raw spectra data is presented in Figure 4c. Each isolate is sorted out as an individual, but close relationships within and between groups are noticeable. Two DF scores were calculated for each spectrum for the three bacterial cell types. 
For in-depth within-group separation DFA was used further (Figures 5-7). PCA of group 27/30/34 shows a clear disassociation of isolate 27 (Figure 5a). DFA from PC scores of isolates 34,30 and 27 was able to correctly classify $100 \%$ of each group's subjects (Figure 5b). DFA based on raw data with cross-validation between isolates 30 and 27 was able to correctly classify $100 \%$ of subjects in the groups and DFA based on raw data with cross-validation between isolate 30 and 34 was able to correctly classify $100 \%$ of subjects in the group 34 and $93.8 \%$ of subjects in the group 30 (Figure $5 c$ ). Thus, the results show that isolate 27 can be effectively differentiated from the other two isolates in the group.

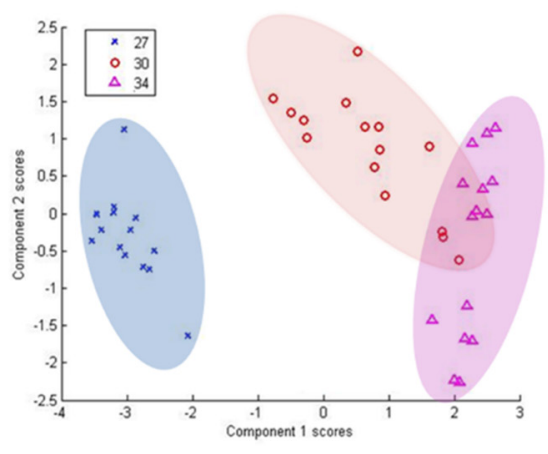

a

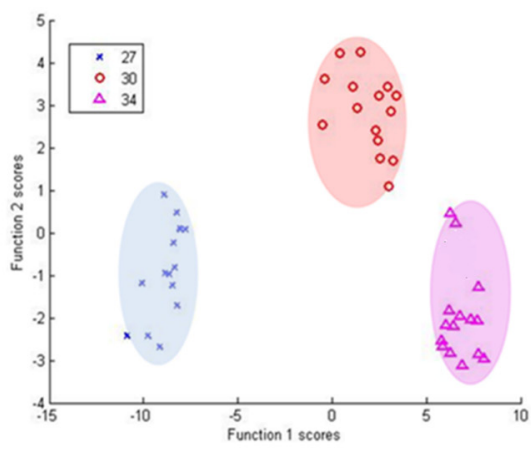

b

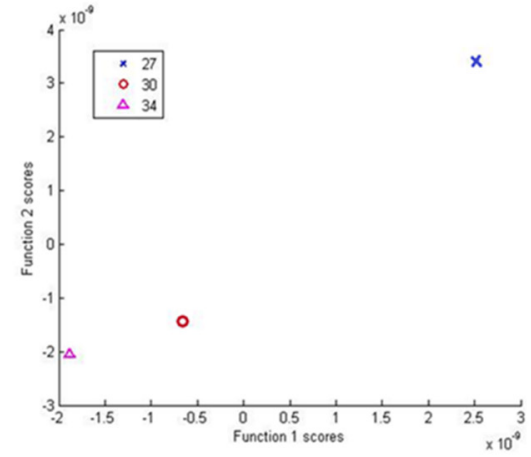

Figure 5. PCA of Pantoea agglomerans group $(27,30,34)(\mathbf{a})$, DFA from PC scores (b) and DFA from raw data (c). Isolate 27 is individually grouped in all 3 analyses, while DFA facilitates clear separation between all the tested isolates.

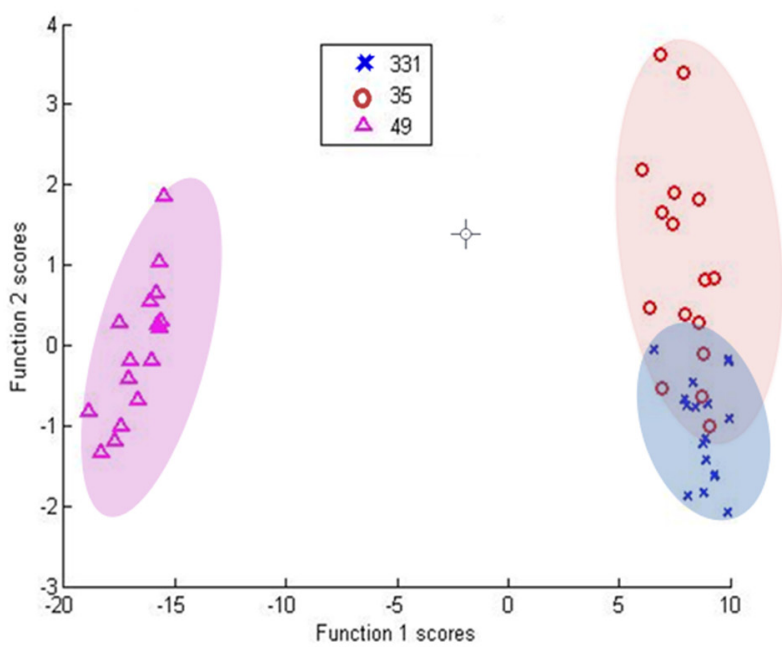

a

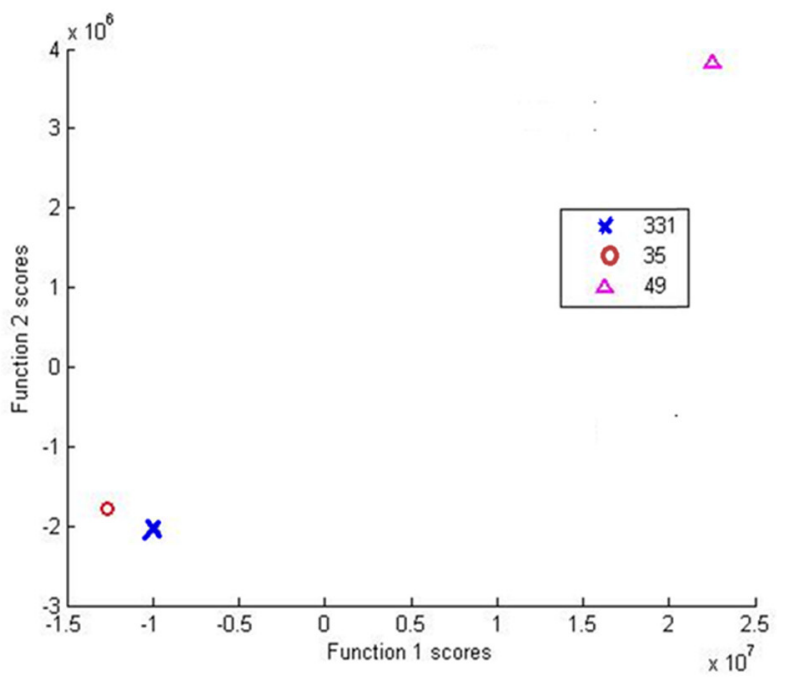

b

Figure 6. DFA of Paenibacillus tundrae group (33.1 and 35) with Pseudomonas isolate 49 as an outlier, as $33.1 / 35$ are highly similar. While DFA from PCA scores shows differentiation with overlaps (a), DFA from raw data (b), while still demonstrating homology, is able to separate isolates 33.1 and 35.

DFA based on PC scores with cross-validation between isolates 33.1 and 35 was able to correctly classify $87.5 \%$ of the group 33.1 subjects and $79.1 \%$ of the group 35 subjects (Figure 6a). The DFA using raw data with cross-validation between 33.1 and 35 was able to correctly classify $100 \%$ of subjects in both groups (Figure $6 \mathrm{~b}$ ).

DFA based on PC scores and from raw data with cross-validation between isolate 37, 49 and 24 was able to correctly classify $100 \%$ of subjects in all the groups (Figure 7). 


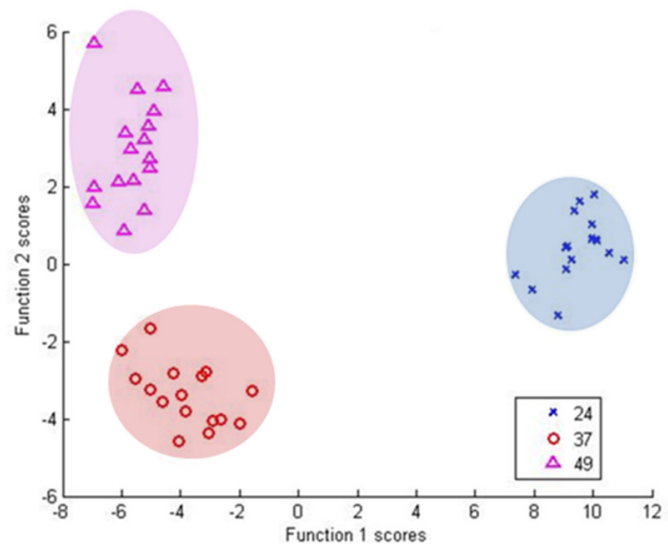

a

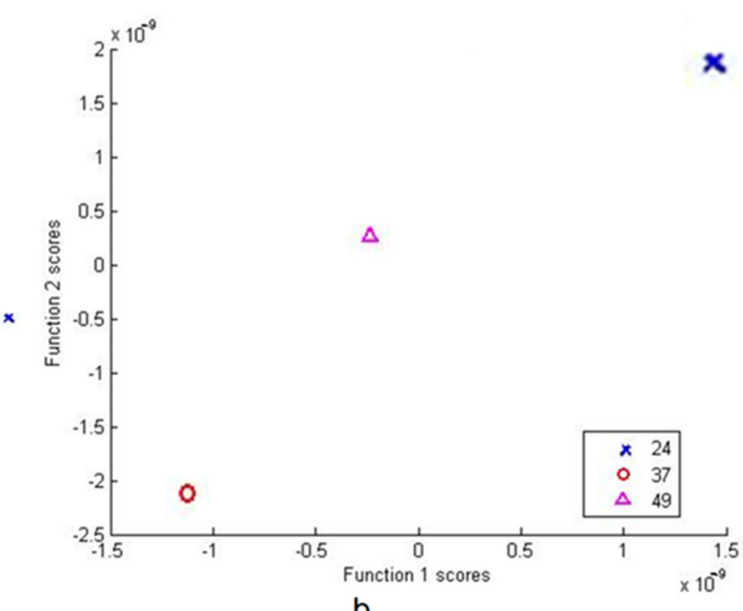

b

Figure 7. DFA based on PCA scores (a) and raw data (b) of Pseudomonas sp. group (37, 49 and 24).

\section{Discussion}

This study showcases that SERS coupled with multivariate cluster analyses can serve as an effective means to achieve bacterial differentiation in plant-associated species, as opposed to standard $16 \mathrm{~S} r \mathrm{RNA}$ gene sequencing and additional antibiotic susceptibility, carbohydrate use, biofilm formation and phenotyping tests.

Additional tests performed during this experiment were able to account for genus level separation. Colony morphology and antibiotic susceptibility tests were more effective than biofilm formation and carbohydrate use studies. Antibiotic susceptibility is considered a strain-level response [80]. Bacterial strains also have been shown to be able to adapt to utilizing new carbohydrates through mutation [81]. Pseudomonas sp. are known biofilm producers [82] and indeed biofilm formation test was able to separate two pseudomonads capable of this. Biofilms are extracellular structures often containing polysaccharides as well as other compounds [3], thus it is possible that evidence of them may be noted in the SERS data, as was shown previously with several species [83-85]. However, it's worth noting that the methodology chosen in this study isn't ideal for yielding data on biofilms created by isolate 24 .

While comparable studies showed that SERS works for pathogenic, medicine and food related, strains $[1,8,9,20]$, based on available information, the usefulness of this technique was not widely studied for plant-associated bacteria [29], or even more specifically for endophytes.

The complexity of the SERS spectrum makes interpretation of the data challenging. Statistical procedures or chemometric multivariate analyses are designed to improve the use and interpretation of experimental data [22]. Chemometrics is defined as a mathematical method used to extract useful information from measured physicochemical data [86].

In this study PCA and DFA, multivariate data analysis techniques, were applied to the SERS spectral data. PCA is one of the multidimensional descriptive methods in chemometrics, particularly fitting for the study of spectral data. This technique provides a synthetic image by presenting factor maps (2D or 3D), in which each spectrum is represented by a dot. The primary variables are replaced with synthetic ones (principal components), which contain all the information $[15,87]$, thus interpreting PCA maps makes it relatively easier to understand the structure of the spectral data [88].

DFA allows for the rapid sorting/grouping of unknown spectra based on betweengroup variability while minimizing within-group variability [6,52]. It also facilitates immediate validation of spectral reproducibility, as very similar spectra should have very similar discriminant function scores and should consequently be closely grouped in DFA. All in all, DFA and PCA are similar in that they both reduce the dimension of the data, but DFA provides better separation between groups of experimental data in comparison to PCA. 
Additionally, while DFA may need a certain level of a priori knowledge about the spectra, PCA is used to examine raw data [87].

PCA has been successfully used for SERS spectra analysis in other bacterial differentiation studies $[1,29,69,89]$. DFA has been used as well, however, less often $[52,63,77]$.

It is noteworthy, that the label-free SERS spectra acquisition protocol presented in this study is an easily replicated approach for procuring bacterial spectra, as bacteria are in an aqueous solution, requiring minimal preparation. Most often comparable procedures either use colloidal solutions or dry out the sample, hence facing difficulties with thermal damage $[9,15]$, which may affect spectra acquisition, as often carbon associated peaks arise in the biologically relevant range [9].

Based on current knowledge, the methodology used in this study likely showcases the metabolic degradation of the tested bacteria, as they are in a no-nutrient environment (salt solution). Nevertheless, as this is linked with specific enzymes each strain may produce and unique metabolic pathways, it too ultimately relates to biochemical differences and thus strain-specific differentiation $[50,53]$. Another recent study demonstrates that SERS peaks may also derive from the constituents of bacterial outer membrane (Gram-) [13].

Moreover, nucleotides are rarely seen in extracellular regions, but notable bands for them have been found in various studies $[9,10,15,26,29]$. Bands in the same regions have been observed in this study as well. For example, an intense peak at $\sim 730 \mathrm{~cm}^{-1}$ is commonly assigned to adenine-type compounds [90]. Furthermore, adenine molecules are part of adenosine triphosphate (ATP), which bacteria use for energy, hence it is possible that their degradation metabolites would end up outside of the bacterial cells, as have been shown with E. coli placed in starvation mode [91] and other studies [50,92].

In this study, bacteria from three different genera were examined. Although certain similarities can be observed in all the tested subjects, i.e., the aforementioned adenosine band at $\sim 730 \mathrm{~cm}^{-1}$, unique vibrational signatures for all of them were successfully obtained. Similar results have been presented previously, whereby E. coli, Listeria monocytogenes and B. subtilis strains were shown to have different SERS spectra $[11,67,89,93]$. Furthermore, Premasiri et al. state that mutations and even genealogy may be observed in their SERS data [11].

While the exact nature of the bacterial Raman/SERS bands is difficult to assign, without mutant bacteria studies, due to peak overlap and minor shifts, bacterial differentiation is still possible $[7,15]$.

Bacterial strains genetically homologous with Pantoea agglomerans have been investigated in previous Raman studies [94]. P. agglomerans vibrational fingerprint reported by Guicheteau et al. resembles those obtained in this study. There were differences though, for example, the peak at $536 \mathrm{~cm}^{-1}$, that the authors attributed to cysteine, asparagine or glutamine, was found shifted in the spectra of isolate 27 , and absent from the other two tested isolates. Moreover, isolate 34 didn't have a notable peak at $958 \mathrm{~cm}^{-1}$. Several peaks demonstrated shifts (ex. at $1004,1142,1544 \mathrm{~cm}^{-1}$ ), while others are absent in the spectra of the strain tested in the cited work [94]. Furthermore, other species from the Pantoea genus have been studied as well $[30,77]$. A study on IAA-producing Pantoea sp. has shown that some notable bands are produced by carotenoids, notably, bands at 1002, 1158 and $1520 \mathrm{~cm}^{-1}$, of which analogs were found in our research as well $\left(\sim 1005,1159,1570 \mathrm{~cm}^{-1}\right)$. Additionally, authors in this study discuss the possibility that the IAA production capacity of this strain may have also been observable, through Trp peaks, as IAA and Trp have similar chemical structures (in fact Trp is a precursor to IAA) [95]. Several Trp associated peaks have been noted in our research as well. This too may potentially be linked to IAA production [35].

The most widely researched Pseudomonas species are P. aeruginosa and P. fluorescens. To our knowledge, pseudomonads homologous to those analyzed in this work, have not yet been characterized using Raman techniques. However, data on P. aeruginosa, have shown some similarities to the pseudomonad spectra examined in this work. Spectra reported by Yang et al. are similar, as they share some peaks with very minor shifts (ex. 655, 730, 920, 
$1328,1470 \mathrm{~cm}^{-1}$ ). A peak near $854 \mathrm{~cm}^{-1}$ (related to $\mathrm{G}$ ) was not observed in isolate 49 , while peaks at 957 and $1091 \mathrm{~cm}^{-1}$, linked with hypoxanthine, A, G and guanosine, were only noted in isolate 24. Furthermore, authors report peaks at 518, 1219 and $1528 \mathrm{~cm}^{-1}$, which were not obtained in this study [63]. Another study on P. aeruginosa also demonstrates peaks, that are comparable to those found in this study [70]. However, most of them are expressed differently in different isolates, peaks at $\sim 690$ and $832 \mathrm{~cm}^{-1}$ (related to G, C and C-O-C stretching according to the authors) are observed only in the data of isolates 37 and 49, while peaks near 958 and $1421 \mathrm{~cm}^{-1}$ (linked with phospholipids or C-O deformations) have only been noted in isolate 24. A study done on P. fluorescens resulted in the SERS peak at $1495 \mathrm{~cm}^{-1}$ [78]. During our research, this peak was found to be one of the discerning factors of isolate 49, homologous with P. azotoformans. This peak has been linked with lipids, proteins and carotenoids (see Table 4).

Plant-associated Paenibacillus validus has exhibited many of the same peaks, as those reported in our study for isolates 35 and 33.1 (958, 1009, 1158, 1363, 1470, 1511, 1570, $1680 \mathrm{~cm}^{-1}$ ) [29]. Nonetheless, the article didn't enlighten on the origins of peaks that discerned the Paenibacillus sp. isolates in our experiment $\left(1398\right.$ and $\left.1116 \mathrm{~cm}^{-1}\right)$.

\section{Conclusions}

A rapid SERS strategy for bacteria differentiation was successfully established by using low-cost AgNP/Si substrates, where other methods (biochemical and genetic testing) have failed. It was found that AgNP 3D film on Si surface was interacting with the bacteria, resulting in strong and reproducible SERS spectra. Surface enhanced Raman spectroscopy coupled with advanced statistical techniques (PCA and DFA) were used to discriminate between different plant bacterial strains of Paenibacillus, Pseudomonas and Pantoea genera by probing the molecular components of their cells. This is the first time, SERS peaks characteristic to bacteria closely related to Pseudomonas azotoformans and P. brenneri/proteolytica have been obtained. Moreover, so far as we were able to determine, this is one of the first studies on the SERS spectra characteristics of Paenibacillus sp. This work progresses the current knowledge of bio-spectroscopy and may help with the introduction of SERS-based bacterial identification technique as a standard method of analysis in plant-associated bacteriology.

Author Contributions: Conceptualization, V.S. and D.V.; methodology, V.S. and D.V.; software, V.S. and D.V.; validation, V.S. and D.V.; formal analysis, V.S. and D.V.; investigation, V.S. and D.V.; resources, V.S. and D.V.; data curation, V.S. and D.V.; writing-original draft preparation, V.S. and D.V.; writing-review and editing, V.S. and D.V.; visualization, V.S. and D.V.; supervision, V.S. All authors have read and agreed to the published version of the manuscript.

Funding: This research received no external funding.

Institutional Review Board Statement: Not applicable.

Informed Consent Statement: Not applicable.

Data Availability Statement: Detailed data concerning this study is available upon request.

Acknowledgments: The authors would like to thank Sigute Kuusiene, for introductions and useful discussions.

Conflicts of Interest: The authors declare no conflict of interest.

\section{References}

1. Witkowska, E.; Korsak, D.; Kowalska, A.; Księżopolska-Gocalska, M.; Niedziółka-Jönsson, J.; Roźniecka, E.; Michałowicz, W.; Albrycht, P.; Podrażka, M.; Hołyst, R.; et al. Surface-enhanced Raman spectroscopy introduced into the International Standard Organization (ISO) regulations as an alternative method for detection and identification of pathogens in the food industry. Anal. Bioanal Chem. 2017, 409, 1555-1567. [CrossRef] [PubMed]

2. Ahmad, W.; Wang, J.; Li, H.; Jiao, T.; Chen, Q. Trends in the bacterial recognition patterns used in surface enhanced Raman spectroscopy. TrAC-Trends Anal. Chem. 2021, 142, 116310. [CrossRef]

3. Chisanga, M.; Muhamadali, H.; Ellis, D.I.; Goodacre, R. Surface-Enhanced Raman Scattering (SERS) in Microbiology: Illumination and Enhancement of the Microbial World. Appl. Spectrosc. 2018, 72, 987-1000. [CrossRef] [PubMed]

4. Efrima, S.; Zeiri, L. Understanding SERS of bacteria. J. Raman Spectrosc. 2009, 40, 277-288. [CrossRef] 
5. Colniţă, A.; Dina, N.E.; Leopold, N.; Vodnar, D.C.; Bogdan, D.; Porav, S.A.; David, L. Characterization and discrimination of gram-positive bacteria using raman spectroscopy with the aid of principal component analysis. Nanomaterials 2017, 7, 28-31. [CrossRef] [PubMed]

6. Jarvis, R.; Clarke, S.; Goodacre, R. Rapid analysis of microbiological systems using SERS. Top. Appl. Phys. 2006, 103, 397-408. [CrossRef]

7. Kairyte, K.; Luksiene, Z.; Pucetaite, M.; Sablinskas, V. Differentiation of bacterial strains by means of surface enhanced ft-raman spectroscopy. Lith. J. Phys. 2012, 52, 276-283. [CrossRef]

8. Kotanen, C.N.; Martinez, L.; Alvarez, R.; Simecek, J.W. Surface enhanced Raman scattering spectroscopy for detection and identification of microbial pathogens isolated from human serum. Sens. Bio-Sens. Res. 2016, 8, 20-26. [CrossRef]

9. Dina, N.E.; Zhou, H.; Colniţă, A.; Leopold, N.; Szoke-Nagy, T.; Coman, C.; Haisch, C. Rapid single-cell detection and identification of pathogens by using surface-enhanced Raman spectroscopy. Analyst 2017, 142, 1782-1789. [CrossRef]

10. Lemma, T.; Saliniemi, A.; Hynninen, V.; Hytönen, V.P.; Toppari, J.J. SERS detection of cell surface and intracellular components of microorganisms using nano-aggregated Ag substrate. Vib. Spectrosc. 2016, 83, 36-45. [CrossRef]

11. Premasiri, R.; Moir, D.; Jones, G.; Ziegler, L.D. Characterization of the Surface Enhanced Raman Scattering of Bacteria on a Novel Sers Substrate. J. Phys. Chem. B 2005, 109, 312-320. [CrossRef]

12. De Plano, L.M.; Fazio, E.; Rizzo, M.G.; Franco, D.; Carnazza, S.; Trusso, S.; Neri, F.; Guglielmino, S.P.P. Phage-based assay for rapid detection of bacterial pathogens in blood by Raman spectroscopy. J. Immunol. Methods. 2018, 465, 45-52. [CrossRef]

13. Yan, Y.; Nie, Y.; An, L.; Tang, Y.Q.; Xu, Z.; Wu, X.L. Improvement of Surface-Enhanced Raman Scattering Method for Single Bacterial Cell Analysis. Front. Bioeng. Biotechnol. 2020, 8, 1-13. [CrossRef]

14. Zhou, X.; Hu, Z.; Yang, D.; Xie, S.; Jiang, Z.; Niessner, R.; Haisch, C.; Zhou, H.; Sun, P. Bacteria Detection: From Powerful SERS to Its Advanced Compatible Techniques. Adv. Sci. 2020, 7, 1-23. [CrossRef]

15. Mosier-Boss, P.A. Review on SERS of bacteria. Biosensors 2017, 7, 51. [CrossRef]

16. Jarvis, R.M.; Brooker, A.; Goodacre, R. Surface-enhanced Raman scattering for the rapid discrimination of bacteria. Faraday Discuss. 2005, 132, 281-292. [CrossRef]

17. Smith-Palmer, T.; Douglas, C.; Fredericks, P. Rationalizing the SER spectra of bacteria. Vib. Spectrosc. 2010, 53, 103-106. [CrossRef]

18. Almasoud, N.; Muhamadali, H.; Chisanga, M.; Alrabiah, H.; Lima, C.A.; Goodacre, R. Discrimination of bacteria using whole organism fingerprinting: The utility of modern physicochemical techniques for bacterial typing. Analyst 2021, 146, 770-788. [CrossRef] [PubMed]

19. Tamer, U.; Torul, H.; Doğan, Ü.; Eryılmaz, M.; Gümüştaş, A.; Boyacı, İ.H.; Özkan, S.A.; Uslu, B. SERS Sensor Applications in Environmental Analysis and Biotechnology. In Nanotechnology Applications in Health and Environmental Sciences; Springer: Cham, Switzerland, 2021; pp. 197-236. [CrossRef]

20. Liu, Y.; Chen, Y.R.; Nou, X.; Chao, K. Potential of surface-enhanced Raman spectroscopy for the rapid identification of Escherichia Coli and Listeria Monocytogenes cultures on silver colloidal nanoparticles. Appl. Spectrosc. 2007, 61, 824-831. [CrossRef]

21. Harz, M.; Rösch, P.; Popp, J. Vibrational spectroscopy-A powerful tool for the rapid identification of microbial cells at the single-cell level. Cytom. Part A 2009, 75, 104-113. [CrossRef] [PubMed]

22. Stöckel, S.; Kirchhoff, J.; Neugebauer, U.; Rösch, P.; Popp, J. The application of Raman spectroscopy for the detection and identification of microorganisms. J. Raman Spectrosc. 2016, 47, 89-109. [CrossRef]

23. Ashton, L.; Lau, K.; Winder, C.L.; Goodacre, R. Raman spectroscopy: Lighting up the future of microbial identification. Future Microbiol. 2011, 6, 991-997. [CrossRef] [PubMed]

24. Patel, I.S.; Premasiri, W.R.; Moir, D.T.; Ziegler, L.D. Barcoding bacterial cells: A SERS-based methodology for pathogen identification. J. Raman Spectrosc. 2008, 39, 1660-1672. [CrossRef]

25. Snitka, V.; Batiuskaite, D.; Bruzaite, I.; Lafont, U.; Butenko, Y.; Semprimoschnig, C. Surface-enhanced Raman scattering sensors for biomedical and molecular detection applications in space. CEAS Sp. J. 2021, 13, 509-520. [CrossRef]

26. Çulha, M.; Adigüzel, A.; Yazici, M.M.; Kahraman, M.; Şahin, F.; Güllüce, M. Characterization of thermophilic bacteria using surface-enhanced Raman scattering. Appl. Spectrosc. 2008, 62, 1226-1232. [CrossRef] [PubMed]

27. Franco, D.; De Plano, L.M.; Rizzo, M.G.; Scibilia, S.; Lentini, G.; Fazio, E.; Neri, F.; Guglielmino, S.P.P.; Mezzasalma, A.M. Bio-hybrid gold nanoparticles as SERS probe for rapid bacteria cell identification. Spectrochim. Acta-Part A Mol. Biomol. Spectrosc. 2020, 224, 117394. [CrossRef]

28. Ho, C.S.; Jean, N.; Hogan, C.A.; Blackmon, L.; Jeffrey, S.S.; Holodniy, M.; Banaei, N.; Saleh, A.A.E.; Ermon, S.; Dionne, J. Rapid identification of pathogenic bacteria using Raman spectroscopy and deep learning. Nat. Commun. 2019, 10, 4927. [CrossRef]

29. Paret, M.L.; Sharma, S.K.; Green, L.M.; Alvarez, A.M. Biochemical characterization of Gram-positive and Gram-negative plant-associated bacteria with micro-raman spectroscopy. Appl. Spectrosc. 2010, 64, 433-441. [CrossRef]

30. Polisetti, S.; Bible, A.N.; Morrell-Falvey, J.L.; Bohn, P.W. Raman chemical imaging of the rhizosphere bacterium Pantoea sp. YR343 and its co-culture with Arabidopsis thaliana. Analyst 2016, 141, 2175-2182. [CrossRef]

31. Kour, D.; Rana, K.L.; Yadav, A.N.; Yadav, N.; Kumar, M.; Kumar, V.; Vyas, P.; Dhaliwal, H.S.; Saxena, A.K. Microbial biofertilizers: Bioresources and eco-friendly technologies for agricultural and environmental sustainability. Biocatal. Agric. Biotechnol. 2020, 23, 101487. [CrossRef]

32. Pirttilä, A.M.; Mohammad Parast Tabas, H.; Baruah, N.; Koskimäki, J.J. Biofertilizers and Biocontrol Agents for Agriculture: How to Identify and Develop New Potent Microbial Strains and Traits. Microorganisms 2021, 9, 817. [CrossRef] [PubMed] 
33. Fan, D.; Subramanian, S.; Smith, D.L. Plant endophytes promote growth and alleviate salt stress in Arabidopsis thaliana. Sci. Rep. 2020, 10, 12740. [CrossRef] [PubMed]

34. Takikawa, Y. Studies on identification and taxonomy of plant pathogenic bacteria. J. Gen. Plant. Pathol. 2012, 78, 409-412. [CrossRef]

35. Vaitiekūnaitè, D.; Kuusienè, S.; Beniušytė, E. Oak (Quercus robur) Associated Endophytic Paenibacillus sp. Promotes Poplar (Populus spp.) Root Growth In Vitro. Microorganisms 2021, 9, 1151. [CrossRef]

36. Oukala, N.; Aissat, K.; Pastor, V. Bacterial endophytes: The hidden actor in plant immune responses against biotic stress. Plants 2021, 10, 1012. [CrossRef]

37. Hardoim, P.R.; van Overbeek, L.S.; Berg, G.; Pirttilä, A.M.; Compant, S.; Campisano, S.; Döring, M.; Sessitsch, A. The Hidden World within Plants: Ecological and Evolutionary Considerations for Defining Functioning of Microbial Endophytes. Microbiol. Mol. Biol Rev. 2015, 79, 293-320. [CrossRef]

38. Bueno-Gonzalez, V.; Brady, C.; Denman, S.; Allainguillaume, J.; Arnold, D. Pseudomonas kirkiae sp. Nov., a novel species isolated from oak in the united kingdom, and phylogenetic considerations of the genera pseudomonas, azotobacter and azomonas. Int. J. Syst. Evol. Microbiol. 2020, 70, 2426-2434. [CrossRef]

39. Govindasamy, V.; Raina, S.K.; George, P.; Kumar, M.; Rane, J.; Minhas, P.S.; Vittal, K.P.R. Functional and phylogenetic diversity of cultivable rhizobacterial endophytes of sorghum [Sorghum bicolor (L.) Moench]. Antonie Leeuwenhoek 2017, 110, 925-943. [CrossRef]

40. Compant, S.; Mitter, B.; Colli-Mull, J.G.; Gangl, H.; Sessitsch, A. Endophytes of Grapevine Flowers, Berries, and Seeds: Identification of Cultivable Bacteria, Comparison with Other Plant Parts, and Visualization of Niches of Colonization. Microb. Ecol. 2011, 62, 188-197. [CrossRef]

41. Premasiri, W.R.; Moir, D.T.; Ziegler, L.D. Vibrational fingerprinting of bacterial pathogens by surface enhanced Raman scattering (SERS). Chem. Biol. Sens. VI 2005, 5795, 19. [CrossRef]

42. Tamošiūnè, I.; Stanienè, G.; Haimi, P.; Stanys, V.; Rugienius, R.; Baniulis, D. Endophytic Bacillus and Pseudomonas spp. Modulate Apple Shoot Growth, Cellular Redox Balance, and Protein Expression Under in Vitro Conditions. Front. Plant. Sci. 2018, 9, 889. [CrossRef] [PubMed]

43. Mohamed, A.; Mhand Rajaa, A.; Khalid, Z.; Fouad, M.; Naima, R. Comparison of Three Methods for the Detection of Biofilm Formation by Clinical Isolates of Staphylococcus aureus Isolated in Casablanca. Int. J. Sci. Res. 2013, 5, 2319-7064. [CrossRef]

44. Johnson, T.R.; Case, C.L. Laboratory Experiments in Microbiology, 11th ed.; Pearson: London, UK, 2015.

45. Bauer, A.W.; Kirby, W.M.; Sherris, J.C.; Turck, M. Antibiotic susceptibility testing by a standardized single disk method. Am. J. Clin. Pathol. 1966, 45, 493-496. [CrossRef]

46. Sarker, M.M.R.; Islam, K.N.; Huri, H.Z.; Rahman, M.; Imam, H.; Hosen, M.B.; Mohammad, N.; Sarker, M.Z.I. Studies of the impact of occupational exposure of pharmaceutical workers on the development of antimicrobial drug resistance. J. Occup. Health 2014, 56, 260-270. [CrossRef]

47. Abdelaziz, E.; Ramadan, H.; Rasha, B.; Shadi, S.; Wael, E.-N. Antimicrobial susceptibility and sodium dodecyl sulfate polyacrylamide gel electrophoresis (SDS-PAGE) typing of Gram negative bacteria isolated from urinary tract infections in Mansoura, Egypt. J. Microbiol. Antimicrob. 2014, 6, 43-50. [CrossRef]

48. Fouad, Z. Antimicrobial Disk Diffusion Zone Interpretation Guide. 2011. [CrossRef]

49. Ramanauskaite, L.; Snitka, V. Surface enhanced Raman spectroscopy of 1-alanyl-1-tryptophan dipeptide adsorbed on Si substrate decorated with triangular silver nanoplates. Chem. Phys. Lett. 2015, 623, 46-50. [CrossRef]

50. Premasiri, W.R.; Lee, J.C.; Sauer-Budge, A.; Théberge, R.; Costello, C.E.; Ziegler, L.D. The biochemical origins of the surfaceenhanced Raman spectra of bacteria: A metabolomics profiling by SERS. Anal. Bioanal. Chem. 2016, 408, 4631-4647. [CrossRef]

51. Available online: https://www.effemm2.de/spectragryph/ (accessed on 9 August 2021).

52. Reisner, L.A.; Cao, A.; Pandya, A.K. An integrated software system for processing, analyzing, and classifying Raman spectra. Chemom. Intell. Lab. Syst. 2011, 105, 83-90. [CrossRef]

53. Kurochkin, I.N.; Eremenko, A.V.; Evtushenko, E.G.; Nechaeva, N.L.; Durmanov, N.N.; Guliev, R.R.; Lagarkov, A.N. SERS for Bacteria, Viruses, and Protein Biosensing. In Macro, Micro, and Nano-Biosensors; Rai, M., Reshetilov, A., Plekhanova, Y., Ingle, A.P., Eds.; Springer: Cham, Switzerland, 2021. [CrossRef]

54. De Gelder, J.; De Gussem, K.; Vandenabeele, P.; Moens, L. Reference database of Raman spectra of biological molecules. J. Raman Spectrosc. 2007, 38, 1133-1147. [CrossRef]

55. Czamara, K.; Majzner, K.; Pacia, M.Z.; Kochan, K.; Kaczor, A.; Baranska, M. Raman spectroscopy of lipids: A review. J. Raman Spectrosc. 2015, 46, 4-20. [CrossRef]

56. Movasaghi, Z.; Rehman, S.; Rehman, I.U. Raman spectroscopy of biological tissues. Appl. Spectrosc. Rev. 2007, 42, 493-541. [CrossRef]

57. Podstawka, E.; Ozaki, Y.; Proniewicz, L.M. Adsorption of S-S containing proteins on a colloidal silver surface studied by surface-enhanced Raman spectroscopy. Appl. Spectrosc. 2004, 58, 1147-1156. [CrossRef] [PubMed]

58. Tian, H.; Zhuang, G.; Ma, A.; Jing, C. Arsenic interception by cell wall of bacteria observed with surface-enhanced Raman scattering. J. Microbiol. Methods. 2012, 89, 153-158. [CrossRef] [PubMed]

59. Su, L.; Zhang, P.; Zheng, D.; Wang, Y.; Zhong, R. Rapid detection of Escherichia coli and Salmonella typhimurium by surfaceenhanced Raman scattering. Optoelectron. Lett. 2015, 11, 157-160. [CrossRef] 
60. Otto, C.; van den Tweel, T.J.J.; de Mul, F.F.M.; Greve, J. Surface-enhanced Raman spectroscopy of DNA bases. J. Raman Spectrosc. 1986, 17, 289-298. [CrossRef]

61. Kögler, M.; Paul, A.; Anane, E.; Birkholz, M.; Bunker, A.; Viitala, T.; Maiwald, M.; Junne, S.; Neubauer, P. Comparison of time-gated surface-enhanced raman spectroscopy (TG-SERS) and classical SERS based monitoring of Escherichia coli cultivation samples. Biotechnol. Prog. 2018, 34, 1533-1542. [CrossRef] [PubMed]

62. Li, J.; Wang, C.; Kang, H.; Shao, L.; Hu, L.; Xiao, R.; Wang, S.; Gu, B. Label-free identification carbapenem-resistant Escherichia coli based on surface-enhanced resonance Raman scattering. RSC Adv. 2018, 8, 4761-4765. [CrossRef]

63. Yang, D.; Zhou, H.; Dina, N.E.; Haisch, C. Portable bacteria-capturing chip for direct surfaceenhanced Raman scattering identification of urinary tract infection pathogens. R. Soc. Open Sci. 2018, 5, 180955. [CrossRef]

64. Meng, X.; Wang, H.; Chen, N.; Ding, P.; Shi, H.; Zhai, X.; Su, Y.; He, Y. A Graphene-Silver Nanoparticle-Silicon Sandwich SERS Chip for Quantitative Detection of Molecules and Capture, Discrimination, and Inactivation of Bacteria. Anal. Chem. 2018, 90, 5646-5653. [CrossRef] [PubMed]

65. Xie, Y.; Xu, L.; Wang, Y.; Shao, J.; Wang, L.; Wang, H.; Qian, H.; Yao, W. Label-free detection of the foodborne pathogens of Enterobacteriaceae by surface-enhanced Raman spectroscopy. Anal. Methods 2013, 5, 946-952. [CrossRef]

66. Wei, C.; Li, M.; Zhao, X. Surface-enhanced raman scattering (SERS) with silver nano substrates synthesized by microwave for rapid detection of foodborne pathogens. Front. Microbiol. 2018, 9, 1-9. [CrossRef] [PubMed]

67. Walter, A.; März, A.; Schumacher, W.; Rösch, P.; Popp, J. Towards a fast, high specific and reliable discrimination of bacteria on strain level by means of SERS in a microfluidic device. Lab. Chip. 2011, 11, 1013-1021. [CrossRef]

68. Rastogi, S.K.; Jabal JM, F.; Zhang, H.; Gibson, C.M.; Haler, K.J.; Qiang, Y.; Branen, A.L. Antibody@silica coated iron oxide nanoparticles: Synthesis, capture of E. coli and SERS titration of biomolecules with antibacterial silver colloid. J. Nanomed. Nanotechnol. 2011, 2, 1000121. [CrossRef]

69. Cozar, I.B.; Colniţă, A.; Szöke-Nagy, T.; Gherman, A.M.R.; Dina, N.E. Label-Free Detection of Bacteria Using Surface-Enhanced Raman Scattering and Principal Component Analysis. Anal. Lett. 2019, 52, 177-189. [CrossRef]

70. Mungroo, N.A.; Oliveira, G.; Neethirajan, S. SERS based point-of-care detection of food-borne pathogens. Microchim. Acta 2016, 183, 697-707. [CrossRef]

71. Ahmed, M.; Almagedi, S.; Yao, W. Sers Signatures of Foodborne Pathogenic Zoonotic Bacteria Using Gold Colloid. Int. J. Eng. Sci. Technol. 2013, 5, 810-821.

72. Fan, C.; Hu, Z.; Mustapha, A.; Lin, M. Rapid detection of food- and waterborne bacteria using surface-enhanced Raman spectroscopy coupled with silver nanosubstrates. Appl. Microbiol. Biotechnol. 2011, 92, 1053-1061. [CrossRef]

73. Jin, H.; Wang, J.; Jin, S.; Jiang, L.; Zou, Y. Raman spectroscopy of potential bio-hazards commonly found in bio-aerosols. Spectrochim. Acta-Part A Mol. Biomol. Spectrosc. 2020, 243, 118753. [CrossRef]

74. Alula, M.T.; Krishnan, S.; Hendricks, N.R.; Karamchand, L.; Blackburn, J.M. Identification and quantitation of pathogenic bacteria via in-situ formation of silver nanoparticles on cell walls, and their detection via SERS. Microchim. Acta 2017, 184, 219-227. [CrossRef]

75. Huang, H.; Liu, M.; Wang, X.; Zhang, W.; Yang, D.-P.; Cui, L.; Wang, X. Label-Free 3D Ag Nanoflower-Based Electrochemical Immunosensor for the Detection of Escherichia coli O157:H7 Pathogens. Nanoscale Res. Lett. 2016, 11, 507. [CrossRef] [PubMed]

76. Uusitalo, S.; Kögler, M.; Välimaa, A.L.; Popov, A.; Ryabchikov, Y.; Kontturi, Y.; Siitonen, S.; Petäjä, J.; Virtanen, T.; Laitinen, R.; et al. Detection of: Listeria innocua on roll-to-roll produced SERS substrates with gold nanoparticles. RSC Adv. 2016, 6, 62981-62989. [CrossRef]

77. Pérez, M.; Contreras, H.; Sosa Herrera, J.A.; Ávila, J.; Tobías, H.; Martínez, F.D.; Ramírez, R.F.; Vázquez, Á. Detection of clavibacter michiganensis subsp. Michiganensis assisted by micro-raman spectroscopy under laboratory conditions. Plant. Pathol. J. 2018, 34, 381-392. [CrossRef] [PubMed]

78. Liu, S.; Li, H.; Hassan, M.M.; Zhu, J.; Wang, A.; Ouyang, Q.; Zareef, M.; Chen, Q. Amplification of Raman spectra by gold nanorods combined with chemometrics for rapid classification of four Pseudomonas. Int. J. Food Microbiol. $2019,304,58-67$. [CrossRef] [PubMed]

79. Kashif, M.; Irfan Majeed, M.; Nawaz, H.; Rashid, N.; Abubakar, M.; Ahmad, S.; Ali, S.; Hyat, H.; Bashir, S.; Batool, F.; et al. Surface-enhanced Raman spectroscopy for identification of food processing bacteria. Spectrochim. Acta. Part A Mol. Biomol. Spectrosc. 2021, 261, 119989. [CrossRef]

80. Lamrabet, O.; Martin, M.; Lenski, R.E.; Schneider, D. Changes in intrinsic antibiotic susceptibility during a long-term evolution experiment with escherichia coli. MBio 2019, 10, 1-12. [CrossRef]

81. Blount, Z.D.; Borland, C.Z.; Lenski, R.E. Historical contingency and the evolution of a key innovation in an experimental population of Escherichia coli. Proc. Natl. Acad. Sci. USA 2008, 105, 7899-7906. [CrossRef]

82. Ramey, B.E.; Koutsoudis, M.; Bodman, S.B.V.; Fuqua, C. Biofilm formation in plant-microbe associations. Curr. Opin. Microbiol. 2004, 7, 602-609. [CrossRef]

83. Bodelón, G.; Montes-garcía, V.; López-puente, V.; Hill, E.H.; Hamon, C.; Sanz-Ortiz, M.N.; Rodal-Cedeira, S.; Costas, C.; Celiksoy, S.; Pérez-Juste, I.; et al. Detection and imaging of quorum sensing in Pseudomonas aeruginosa biofilm communities by surface-enhanced resonance Raman scattering. Nat. Mater. 2017, 15, 1203-1211. [CrossRef]

84. Schkolnik, G.; Schmidt, M.; Mazza, M.G.; Harnisch, F.; Musat, N. In situ analysis of a silver nanoparticle-precipitating Shewanella biofilm by surface enhanced confocal raman microscopy. PLoS ONE 2015, 10, 7-12. [CrossRef] 
85. Baig, N.; Polisetti, S.; Morales-Soto, N.; Dunham, S.J.B.; Sweedler, J.V.; Shrout, J.D.; Bohn, P.W. Label-free molecular imaging of bacterial communities of the opportunistic pathogen Pseudomonas aeruginosa. Biosensing Nanomed. IX 2016, 9930, 993004. [CrossRef]

86. Szymańska, E.; Gerretzen, J.; Engel, J.; Geurts, B.; Blanchet, L.; Buydens, L.M.C. Chemometrics and qualitative analysis have a vibrant relationship. TrAC-Trends Anal. Chem. 2015, 69, 34-51. [CrossRef]

87. Jolliffe, I.T. Principal Component Analysis. In Encyclopedia of Statistics in Behavioral Science, 2nd ed.; Everitt, B.S., Howell, D.C., Eds.; Springer: NewYork, NY, USA, 2002; Volume 30, p. 487. [CrossRef]

88. Guo, S.; Rösch, P.; Popp, J.; Bocklitz, T. Modified PCA and PLS: Towards a better classification in Raman spectroscopy-based biological applications. J. Chemom. 2020, 34, 1-10. [CrossRef]

89. Witkowska, E.; Korsak, D.; Kowalska, A.; Janeczek, A.; Kamińska, A. Strain-level typing and identification of bacteria-a novel approach for SERS active plasmonic nanostructures. Anal. Bioanal. Chem. 2018, 410, 5019-5031. [CrossRef] [PubMed]

90. Kubryk, P.; Niessner, R.; Ivleva, N.P. The origin of the band at around $730 \mathrm{~cm}-1$ in the SERS spectra of bacteria: A stable isotope approach. Analyst 2016, 141, 2874-2878. [CrossRef]

91. Brauer, M.J.; Yuan, J.; Bennett, B.D.; Lu, W.; Kimball, E.; Botstein, D.; Rabinowitz, J.D. Conservation of the metabolomic response to starvation across two divergent microbes. Proc. Natl. Acad. Sci. USA 2006, 103, 19302-19307. [CrossRef]

92. Link, H.; Fuhrer, T.; Gerosa, L.; Zamboni, N.; Sauer, U. Real-time metabolome profiling of the metabolic switch between starvation and growth. Nat. Methods 2015, 12, 1091-1097. [CrossRef]

93. Sharma, S.K.; Dykes, A.C.; Misra, A.K.; Kamemoto, L.E.; Bates, D.E. Raman discrimination of bacterial strains using multilayered microcavity substrates. Smart Biomed. Physiol. Sens. Technol. VIII 2011, 8025, 802508. [CrossRef]

94. Guicheteau, J.; Argue, L.; Hyre, A.; Jacobson, M.; Christesen, S.D. Raman and surface-enhanced Raman spectroscopy of amino acids and nucleotide bases for target bacterial vibrational mode identification. Chem. Biol. Sens. VII 2006, 6218, 62180O. [CrossRef]

95. Polisetti, S.; Baig, N.; Bible, A.; Morrell-Falvey, J.; Doktycz, M.; Bohn, P.W. Using Raman spectroscopy and SERS for in situ studies of rhizosphere bacteria. Biosensing Nanomed. VIII 2015, 9550, 95500D. [CrossRef] 